\title{
As the Snow Melts before the Sunbeam: Writing the "Inevitable" Extinction of the Indigenous Peoples of the Americas
}

Nasha Mavalvala

Nasha Mavalvala is an undergraduate student at $\mathrm{U}$ of $\mathrm{T}$, whose academic interests include Caribbean Studies, African Studies, and Women \& Gender Studies. She is on the Caribbean Studies and Equity Studies Students' Unions, and aims to develop her academic practice alongside community organizing, continuing to search for holistic ways to engage in the multiple and traversing processes of decolonial, feminist \& socialist liberation.

Maximilian Forte asserts that "Indigenous peoples have been ever vanishing, almost as if disappearance was their predetermined historical role" (Forte, 1). This paper will speak to the various techniques of erasure that have historically served to remove indigenous peoples from their lands and detach them from their cultures. Using examples from European, North American, and Caribbean texts, I will discuss the myths of perpetual extinction of Indigenous peoples and how these myths have worked to annihilate the indigenous population-both culturally and physically-through fictitious repetitions within literature such as plays and poetry, but also through government documents, records and the enactment of policies of erasure. Forte writes, "One of the dominant myths of extinction, wrapped in terms of the then dominant evolutionism, had to do with extinction via miscegenation, a purely racial argument. No "pure" Amerindian equals no Amerindian." I will address this in the context of the historical roots of racial classification and some of the contemporary issues surrounding racial determination. I suggest that since contact, the indigenous have been represented as perpetually dying out, and I discuss the concepts of predetermination and self-fulfilling prophecy in reference to this. "These things seem mysterious," a Bostonian conceded in 1841, "but it would be impious to murmur at the decrees of fate" (Dippie, 12). In the National Uncanny, Renee Bergland writes, "The ghosting of Indians is a technique of removal" (Bergland, 4), referring to the widespread invocation of Native American ghosts in American $19^{\text {th }}$ and $2 \mathrm{O}^{\text {th }}$ century classic literature. My definition of ghosting in application to this paper is the actual practices used to erase the lived histories of Indigenous peoples and used to deny their current existence and rights to self-determination. Omitting literal ghosts and spirits, I will use the aforementioned bodies of literature to 
demonstrate how they employ the techniques of "ghosting" and erasure, diminishing indigenous presence through the falsification of a people's history.

In the National Uncanny: Indian Ghosts and American Subjects, Renee Bergland writes, "The ghosting of Indians is a technique of removal. By writing about Indians as ghosts, white writers effectively remove them from American lands, and place them, instead, within the American imagination" (Bergland, 4). While Bergland's work centers around American literature and popular culture, her theory of removal by placing the Native within the imagination can also be applied to a post-colonial reading of Shakespeare's The Tempest. This will not attest to Shakespeare's intentions or mindset when writing the play, but simply as one understanding of this text. Specifically through the characters of Caliban and Sycorax, forces of erasure are at work in The Tempest. Written into popular imagination as a savage, sub-human "demidevil," Caliban's dehumanization pervades the popular consciousness of Colonial Britain.

What have we here-a man or a fish?-dead or alive?

A fish, he smells like a fish; a very ancient and

fish-like smell; a kind of not-of-the-newest poor-John.A

strange fish! Were I in England now, as once I was, and

had but this fish painted, not a holiday-fool there but

would give a piece of silver. There would this monster

make a man-any strange beast there makes a man.

When they will not give a doit to relieve a lame beggar, they will lay out ten to see a dead Indian. Legged like a man, and his fins like arms! Warm o' my troth! I do now let loose my opinion, hold it no longer: this is no fish, but an islander, that hath lately suffered by a thunderbolt. (2.2.24-35)

Here Caliban is being observed by Trinculo during his first encounter with him. The immediate questioning of his humanity, "What have we here-a man or a fish?" and simultaneously that of his being, "dead or alive," removes the possibility of his personhood. Even when Trinculo decides that he is "no fish, but an islander," his lesser humanness has already been established within the audience. Trinculo thinks about the possibility of profiting from Caliban, "a dead Indian," though alive; already he has been relegated to a position of death. The erasure of indigenous peoples also can be interpreted through the absent character of Sycorax, Caliban's 
mother. She is invoked quite often during the play, but only to indicate her absence. She is never able to voice her account of her story. Her deprivation of voice and the telling of her story through European voices is significant in Sycorax's erasure and in her lack of access to have power in the story. It is not a negative absence of speech but a positive removal of voice. In addition, the fact that Sycorax was born in Algiers is made very evident. Craton writes of the European view of the Black Caribs, that "to emphasize the African origins of the windward Caribs was, of course, to stress that...they were no more indigenous than the Europeans" (Craton, 72). Sycorax is from Algiers but is at the same time equated to being indigenous to the island, suggesting that there are no actual natives present and claims to the island are just as much-or more soEuropean, than they are African.

Then was this island-Save for the son that she did litter here, A freckled whelp, hag-born-not honoured with A human shape. (1.2.281-4)

The notions of non-existence of the indigenous peoples have been continuous since very soon after contact. The construction of the island as absent of humans (except for Caliban, who here is admitted to as human while he simultaneously dehumanized), is parallel to the initial and current rhetoric of "discovery" of the Americas by Columbus and Europeans. This idea in itself removes the original inhabitants of the land. In Racism and National Consciousness, Frederick Case speaks of the notion of the master, recognizing that in his mind, "he possesses an inalienable right over the land. He does not simply own it (a basic notion of capitalist civilization), he is master of it (a basic distorted vision of the relationship between humans and their environment)" (Case, 123). The colonizer claims this already inhabited land as his own. In his mind, he has discovered this land, and he settles his people on this newly "found" land. In this sense, the master also believes he possesses an inalienable right over the people of this land; the enslaver believes the same of the enslaved. By treating these peoples as objects, labeling them as savage, backwards, and barbaric, dehumanization is thus achieved. The widely spread concept of the Europeans' discovery of the Americas "is an insult which reduces the original inhabitants of the Americas to a non-people, less than savages, simple animals. The notion implies that no human civilization had existed on this continent before the arrival of Europeans" (Case, 124). This denial of humanity serves to distance 
the oppressive forces from those they are oppressing, allowing, in effect, a kind of absolution of moral guilt.

In The Vanishing American, Brian Dippie argues that the myth of the perpetually vanishing Native American became selffulfilling, as it "accounted for the Indians' future by denying them one" (Dippie, xii). "The point was no longer whether or not the native population had declined in the past but that its future decline was inevitable" (Dippie, xii). Focusing on the $19^{\text {th }}$ century onwards, Dippie demonstrates that the poetry and the general body of literature of the time started to heavily employ the rhetoric and imagery of nature to explain the fate of the indigenous peoples of the Americas. "The Indian was at the sunset of his existence; night was about to swallow a race fated to vanish 'as the snow melts before the sunbeam,' or 'like the morning dew, insensibly and mysteriously to disappear, before the lights of civilization and Christianity" (Hale, 1819; cited in Dippie, 13). This kind of ephemeral and biological language suggests the "inevitability" and "naturalness" of the decline of indigenous peoples in a way that appeases the national consciousness. Snow must eventually melt, after all, under the fatal sunbeam of European contact. Sentiments such as William Tudor Jr.'s in 1815 regarding 'the extinction of our savage precursors before the dawn of science and cultivation," (cited in Dippie, 13) allowed for the disavowal of American complicity in the devastation of indigenous peoples and instead made the Native Americans responsible for their own demise, as their barbarism and unwillingness or inability to adhere to Western "civilization" and "progress" made it natural that they must perish.

In his evaluation of the widely popular Hollywood film Avatar, Zizek asserts that it "teaches us that the only choice the aborigines have is to be saved by the human beings or to be destroyed by them. In other words, they can choose either to be the victim of imperialist reality, or to play their allotted role in the white man's fantasy." As many colonial voices maintain, the indigenous simply could not be saved from their savageness. In his essay "The Black Caribs of St. Vincent," Michael Craton shows that "without acknowledgment, [the British] echoed the sentiments of Columbus and his successors that good natives submitted to authority and had thereby the chance of redemption through being assimilated to European culture, whereas the obdurate were irredeemable savages fit to be enslaved if not extirpated" (Craton, 71). "Laws cannot reach them in their woods:" this statement made by William Young in his 
report to the colonial government in 1795 reflects the common view of their inherent savagery and innate disposition to backwardness and barbarism. Thus, indigenous peoples are blameworthy for their own "unavoidable" degeneration while at the same time their predetermined dissipation is seen as natural as that of dew.

\section{"The way they wrote us out of history, we will write ourselves back in" -aniki Reyes Ocasio, BorinquenTaino}

Indigenous peoples were and still are attempted to be written out of existence through the severe underestimation of numbers and the perpetual decline of population.

The poor Indians have resisted the pressure of civilisation, and finally sunk under the ascendancy of a more intelligent race. In the year 1783, the Indian population amounted to 2,032 souls, who, at the capitulation of the island, had declined, according to official returns, to 1,082 individuals. In the year 1830 there still existed 689 survivors of that race... At present [1858] there cannot be above 200 or 300 Indians in the colony, so that the aborigines may be said to be almost extinct. (De Verteuil, 173)

And again in 1767: "There were, [Young] claimed, no more than 2,000 Vincentian Caribs in all (an understatement by perhaps 80 Percent), of whom the Yellow descendants of the original inhabitants were no more than a tiny minority" (Craton, 73). In his 1795 An Account of the Black Charaibs on the Island of St. Vincent, William Young reported that "The island was at that time [in 1763] inhabited by about 3000 Black Charaibs, or free Negroes, by 4000 French (their Negroes included), and by about 100 Red Charaibs, or Indians; so reduced were that aboriginal people!" (Young, 18) Implicated in these statements are not only questions of numbers of Indigenous peoples but the designation of who is Indigenous. Young's claim of the Black Caribs as "Negro usurpers" of "real" Caribs customs and heritage are parallel with current ideas of "pure blood," qualifications, the governments' deciding of who is indigenous, and the denying of self-determination. In speaking of the case of Trinidad \& Tobago, Maximilian Forte writes:

When it became desirable to dispossess the Amerindians of lands that were theirs, and were inalienable, the colonial project became one of defining them out of existence, so that their lands could be put up for sale. No purity meant no Amerindians which meant no Amerindian lands. Residence in the Mission of Santa 
Rosa in Arima was determined by race: mixed-race offspring were no longer bound to the mission and could not in the future lay any claim to the mission lands. It mattered not that they were raised by Amerindian mothers, and may have identified themselves as Amerindian, what mattered was their "racial mixture."

In an article entitled, "Does Trinidad Recognize its Indigenous People?” Maximilian Forte writes:

The fact of the matter is that the Government of Trinidad and Tobago has no legal definition of the term "indigenous peoples," and frequently appropriates the term for referring to all people born in the country, in contradiction to established international conventions. Secondly, the Government has recognized only one specific organization, and worse yet, it has recognized it in a manner that suggests it is the only possible representative of Trinidad's "Amerindians," rendering any other claimants to an indigenous identity as fakes. Thirdly, while claiming to recognize the Caribs, the Government has not signed any international conventions or agreements that pertain specifically to the rights of indigenous peoples. (Emphasis in original)

The United Nations Committee for the Elimination of Racial Discrimination "asked why the Caribs had all but disappeared, exactly how many were left, why they were not treated as a separate racial group and whether measures were being taken to help them, particularly in the economic and educational fields, so as to compensate them for the injustices they had suffered."From the above passages, many complications arise. Who gets the right to identify or classify someone as indigenous or non-indigenous? As has been displayed above, racial mixtures such as the community of the Black Caribs, presently known as Garifuna, were constantly denied legitimacy of Indigeneity. Questions of cultural survival versus racial distinctions are essential to these complex issues. As Forte writes in his Indigenous Resurgence in the Contemporary Caribbean, "One can certainly speak of survival in the commonly accepted sense of the term, but cultural survival raises certain problems. Is culture to be likened to a biological organism, with a 'life' and 'death,' and once 'dead' can never be resurrected? This would not be the consensus in anthropology, especially where the ideational concept of culture is treated like a dynamic system of meanings, and meanings do not live natural "lives" (Forte, 10). Forte aptly asserts that "how one is 'Indian' in 2006 will not be the same as in 1492" (Forte, 10). 
"National consciousness, which is not nationalism, is the only thing that will give us an international dimension"

- Frantz Fanon, Wretched of the Earth, p.179.

In World's Within, Vilashini Cooppan writes: "Race precludes what nation promises; race imprisons whereas nation liberates, inventing everything anew, from the structures of familial organization to the language of national community to decolonization's famous 'creation of new men" (Coopan, 141). Race necessarily plays a pivotal role in the issues surrounding the question of Indigeneity. How does being marginalized within a geographical area of world marginalization differ from being marginalized in a "developed" or "First world" country? In both instances, the indigenous are not included as citizens of the nation or in the making of a "national identity;" where they are included in the national consciousness is in the form of gift shop souvenirs of a cultural heritage or past. Can the indigenous peoples of the Caribbean be seen as the periphery within the periphery? Or does this lead to an "oppression Olympics" in a region where the struggle of AfroCaribbean peoples and the Black consciousness movement have been struggling to form a self-determining national consciousness? Bergland writes, "On the one hand, America is and always has been a colony of Europe; on the other, America is an imperial power. But both of these facts are somehow shameful in the American context, since American nationhood is built in the denial of colonialism" (Bergland, 13, emphasis added).

In North America the ghosting of Natives can represent or be a manifestation of repressed 'white guilt' because the nation is built on foundations of White Supremacy and this notion is constantly reified in post-colonial America. But the Caribbean, the construction of Caribbean nationhood, rather than being built in the denial of colonialism, is rooted in the historical and current recognition of colonialism, its legacies, and in anti-colonial struggle. Whereas America denies colonialism and therefore remains in its uncomfortable relationship with it, the Caribbean is a site of decolonization, as it seeks to educate and detach from the bonds of colonial thought. In order to do this, the states of the Caribbean must necessarily take into account its diverse population, including (and perhaps especially) their Indigenous peoples, as a truly decolonized nation cannot deny the political, cultural, or social existence of any of its citizens. Forte claims that theses of extinction "have been a 
hallmark of island Caribbean historiography." He continues, "On the other hand, challenges to notions of disappearance, efforts to resist political and economic marginalization, the formation of new regional organizations, and the recent growth in a committed body of scholarship focused on these issues, collectively produce resurgence. In all cases, contemporary indigenous peoples of the Caribbean refuse to be measured by the relics of their past or to be treated condescendingly as mute testimonials to a disappearing history, or a "history of disappearance" (Forte, 3). 


\section{Works Cited}

Bergland, Renee. "Indian Ghosts and American Subjects," National Uncanny: Indian Ghosts and American Subjects. Hanover: University Press of New England, 2000. 1-24.

Case, Frederick Ivor. Racism and National Consciousness. Toronto: Other Eye Books, 2002.

Cooppan, Vilashini. "Ghostly Forms: Race, Nation and Genre in Frantz Fanon," Worlds Within: National Narratives and Global Connections in Postcolonial Writing. Stanford: Stanford University Press, 2009. 140180.

Craton, Michael. "The Black Caribs of St. Vincent: A Reevaluation," The Lesser Antilles in the Age of European Expansion.Gainsville: University Press of Florida, 1996. 71-85.

De Verteuil, Louis Antoine Aimé. "Chapter V. Population-EthnographyReligion-Education-Crime," Trinidad: Its Geography, Natural Resources, Administration, Present Condition, and Prospects. London: Ward \& Lock, 1858. 171-205.

Dippie, Brian. The Vanishing American: White Attitudes and U.S. Indian Policy. Middletown: Wesleyan University Press, 1982.

Fanon, Frantz."The Pitfalls of National Consciousness," The Wretched of the Earth. New York: Grove Press, 1963. 148-205.

Forte, Maximilian C. "Introduction: The Dual Absences of Extinction and Marginality-What Difference Does an Indigenous Presence Make?" Indigenous Resurgence in the Contemporary Caribbean. New York: Peter Lang Publishing, 2006. 1-18.

Maximilian C. Forte. "Carib Identity, Racial Politics, \& the Problem ofBelonging."Review of the indigenous Caribbean. 1 May 2011..<http://indigenousreview.blogspot.ca/2011/05/caribidentity-racial-politics-problem.html>.

Maximilian C. Forte. "Does Trinidad Recognize Its Indigenous People?." Review of the Indigenous Caribbean. 10 March 2007. $<$ http://indigenousreview.blogspot.ca/2007/03/does-trinidadrecognize-its-indigenous.html>. 
CARIBBEAN QUILT | 2013

Shakespeare, William. The Tempest. New York: Oxford University Press, 1987.

Young, William. An Account of the Black Charaibs in the Island of St. Vincent's, with the Charaib Treaty and other Original Documents, compiled from the papers of the Late Sir William Young, Esq. London: J. Sewell, Knight and Triphook, 1795. 